\title{
Purified Cytochrome $b$ from Human Granulocyte Plasma Membrane is Comprised of Two Polypeptides with Relative Molecular Weights of 91,000 and 22,000
}

\author{
Charles A. Parkos, Rodger A. Allen, Charles G. Cochrane, and Algirdas J. Jesaitis \\ Research Institute of Scripps Clinic, Department of Immunology, La Jolla, California 92037
}

\begin{abstract}
A new method has been developed for purification of cytochrome $b$ from stimulated human granulocytes offering the advantage of high yields from practical quantities of whole blood. Polymorphonuclear leukocytes were treated with diisopropylfluorophosphate, degranulated and disrupted by nitrogen cavitation. Membranes enriched in cytochrome $b$ were prepared by differential centrifugation. Complete solubilization of the cytochrome from the membranes was achieved in octylglucoside after a 1-M salt wash. Wheat germ agglutininconjugated Sepharose 4B specifically bound the solubilized cytochrome $b$ and afforded a threefold purification. Eluate from the immobilized wheat germ agglutinin was further enriched by chromatography on immobilized heparin. The final 260-fold purification of the b-type cytochrome with a 20-30\% yield was achieved by velocity sedimentation in sucrose density gradients. Sodium dodecyl sulfate-polyacrylamide gel electrophoresis (SDS-PAGE) of the purified preparation revealed two polypeptides of $M_{r} 91,000$ and $M_{r} 22,000$. Treatment of the ${ }^{125} I$-labeled, purified preparation with peptide: $N$-glycosidase $F$, which removes $N$-linked sugars, decreased relative molecular weight of the larger species to $\sim 50,000$, whereas beta-elimination, which removes $O$-linked sugars, had little or no effect on the mobility of the $M_{r}-91,000$ polypeptide. Neither of the deglycosylation conditions had any effect on electrophoretic mobility of the $M_{r}-22,000$ polypeptide. Disuccinimidyl suberate cross-linked the two polypeptides to a new $M_{r}$ of $120,000-135,000$ by SDS-PAGE. Antibody raised to the purified preparation immunoprecipitated spectral activity and, on Western blots, bound to the $M_{r}-22,000$ polypeptide but not the $M_{r}-91,000$ polypeptide. Western blot analysis of granulocytes from patients with $\mathrm{X}$ linked chronic granulomatous disease revealed a complete absence of the $M_{r}-22,000$ polypeptide. These results $(a)$ suggest that the two polypeptides are in close association and are part of the cytochrome $b,(b)$ provide explanation for the molecular weight discrepancies previously reported for the protein, and (c) further support the involvement of the cytochrome in superoxide production in human neutrophils.
\end{abstract}

Publication No. 4084 IMM from the Department of Immunology, Research Institute of Scripps Clinic.

Address correspondence to Algirdas J. Jesaitis, Ph.D., Department of Immunology, IMM 12, Research Institute of Scripps Clinic, 10666 North Torrey Pines Road, La Jolla, CA 92037.

Received for publication 18 November 1986 and in revised form 27 February 1987

J. Clin. Invest.

(C) The American Society for Clinical Investigation, Inc. $0021-9738 / 87 / 09 / 0732 / 11 \quad \$ 2.00$

Volume 80, September 1987, 732-742

\section{Introduction}

Neutrophils play a crucial role in defending the body against invading pathogens (1-3). Stimulation of these granulocytes with bacteria or other chemoattractants results in the release of microbicidal oxidants into phagolysosomes or the immediate environment (4-6). The mechanism by which neutrophils produce oxidants, however, is not fully understood.

Evidence suggests that an inducible electron transport system that transfers reducing equivalents from NADPH to oxygen is the source of oxidant production $(7,8)$. The terminal component of this electron transport system is believed to be a low-potential $b$-type cytochrome $(9,10)$. Support for the involvement of this cytochrome $b$ in oxidant production has been obtained from $(a)$ its spectrophotometric absence in patients with certain forms of chronic granulomatous disease (CGD) ${ }^{1}$ whose neutrophils can not mount a respiratory burst (11); (b) genetic complementation studies of oxidant production by the hybridization of monocytes from cytochrome $b$ positive and cytochrome $b$-negative CGD patients to reconstitute the production of oxidants $(12) ;(c)$ copurification of cytochrome $b$ along with $\mathrm{O}_{2}^{-}$-generating activity in detergent extracts $(13,14) ;(d)$ its unusually low $(-245 \mathrm{mV})$ electrochemical potential $(15,16)$; and $(e)$ its anaerobic reduction upon oxidase activation (10) followed by rapid reoxidation after introduction of oxygen into the system (15). Recently, four different groups have reported the purification of cytochrome $b$ from human, bovine, and porcine leukocytes. Relative molecular weight estimates, obtained from SDS-PAGE analyses, were diverse, ranging from 11,000 to 14,000 for bovine leukocytes (17), 32,000 for porcine neutrophils (18), $68,000-80,000$ for human myelogenous leukemia cells (19), and 127,000 for purified human neutrophils (20). These preparations also varied significantly in their reported homogeneity, specific activity, and methods of purification.

In this report, we describe a new method of purification and partial characterization of cytochrome $b$ obtained from cytochalasin-treated human neutrophils stimulated by $N$-formyl-Met-Leu-Phe. The purification procedure we describe yields highly purified cytochrome $b(19.2 \mathrm{nmol}$ heme/mg protein) from readily obtainable quantities of whole blood (3-6 $U)$. The purified preparations were used to produce antibodies and perform electrophoretic and carbohydrate analyses. Our

1. Abbreviations used in this paper: ABTS, 2,2-azino-di-(3-ethylbenzthioline sulfonic acid; CGD, chronic granulomatous disease; CRB, column running buffer; DFP, diisopropyl fluorophosphate; DPBS, Dulbecco's phosphate-buffered saline; DPBS $^{+}$, DPBS plus $0.1 \%$ glucose and $0.1 \%$ BSA; DSS, disuccinimidyl suberate; MRB, membrane resuspension buffer; PMN, polymorphonuclear neutrophilic leukocyte; PMSF, phenylmethyl sulfonyl fluoride; WGA-4B, wheat germ agglutinin-conjugated Sepharose 4B. 
results suggest that purified cytochrome $b$ is composed of two polypeptides; a heavily glycosylated, $M_{r}-91,000$ species and a $M_{r}-22,000$ species which may not be glycosylated. Our finding of both high- and low-molecular-weight polypeptides in the purified cytochrome $b$ preparation may help explain the molecular weight discrepancies reported in the literature.

Lastly, Western blotting studies failed to detect any $M_{r}-22,000$ polypeptide in extracts of neutrophils from patients with the X-linked form of CGD. This result further supports a central role of cytochrome $b$ in superoxide production. Portions of this work have been previously published in abstract form (21).

\section{Methods}

Reagents. $N$-Formyl-Met-Leu-Phe, dihydrocytochalasin $\mathrm{B}, \mathrm{Na}_{2} \mathrm{ATP}$, ovalbumin bovine serum albumin, chymostatin, poly-L-lysine (mol wt 14,000) $\mathrm{N}$-acetylglucosamine, 2,2-azino-di-(3-ethylbenzthioline sulfonic acid) (ABTS), and fetuin type IV were purchased from Sigma Chemical Co., St. Louis, MO. Catalase, superoxide dismutase, phenylmethylsulfonyl fluoride (PMSF), octylglucoside, and dithiothreitol were purchased from Calbiochem Behring Corp., La Jolla, CA. Gelatin and sodium dithionite were obtained from Fisher Scientific, Pittsburgh, PA. $N$-2-hydroxyethyl piperazine- $N$-2-ethane sulfonic acid (Hepes) was purchased from United States Biochemical Corp., Cleveland, OH. EDTA and EGTA were obtained from Fluka AG, Hauppage, NY. Ultrapure Triton X-100 was purchased from Boehringer Mannheim GmbH, Mannheim, FRG. Wheat germ agglutinin was purchased from Vector Laboratories Inc., Burlington, CA. Cyanogen bromide-activated Sepharose 4B and low-molecular-weight protein standards were purchased from Pharmacia Inc., Upsala, Sweden. SDS, acrylamide, bis-acrylamide, Tween 20 , sodium persulfate, peroxidase color developer, $N, N, N, N$,-tetramethylenediamine (TEMED) was purchased from Bio-Rad Laboratories, Richmond, CA. Prestained high-molecular-weight protein standards for SDS gels were purchased from Bethesda Research Laboratories, Gaithersburg, MD. Glycerol, Coomassie Brilliant Blue G-250, and 2-mercaptoethanol were from J. T. Baker Chemical Co., Phillipsburg, NJ. Peptide: $N$-glycosidase F was purchased from Genzyme Corp., Boston, MA. Sucrose and ultrapure urea were acquired from Schwarz-Mann, Spring Valley, NY. Chitobiose was purchased from E. Y. Laboratories Inc., San Mateo, CA. Heparin ultrogel was obtained from LKB Instruments Inc., Bromma, Sweden. Disuccinimidyl suberate, Iodobeads, and BCA protein assay reagent were purchased from Pierce Chemical Co., Rockford, IL. Fluorescamine was obtained from Roche (Nutley, NJ). Freund's Adjuvant was from Difco Laboratories Inc., Detroit, MI. Peroxidase-conjugated goat anti-rabbit IgG was obtained from Tago Inc., Burlingame, CA. Nitrocellulose sheets were purchased from Millipore/Continental Water Systems, Bedford, MA.

Buffer composition. Cell resuspension buffer was a modified Dulbecco's phosphate-buffered saline (DPBS) containing $5 \mathrm{mM} \mathrm{KCl}, 147$ $\mathrm{mM} \mathrm{NaCl}, 1.9 \mathrm{mM} \mathrm{KH}_{2} \mathrm{PO}_{4}, 1.1 \mathrm{mM} \mathrm{K}_{2} \mathrm{HPO}_{4}, 1.5 \mathrm{mM} \mathrm{CaCl}_{2}, 1.1$ $\mathrm{mM} \mathrm{MgCl}_{2}$ (pH 7.4) (DPBS[-]), to which $0.1 \%$ glucose and $0.1 \%$ bovine serum albumin (BSA) was added (DPBS[+]). Nitrogen cavitation buffer consisted of $100 \mathrm{mM} \mathrm{KCl}, 10 \mathrm{mM} \mathrm{NaCl}, 10 \mathrm{mM}$ Hepes, 3.5 $\mathrm{mM} \mathrm{MgCl}_{2}$, and $1 \mathrm{mM} \mathrm{ATP} \mathrm{(pH} \mathrm{7.3).} \mathrm{Membrane} \mathrm{resuspension} \mathrm{buffer}$ (MRB) consisted of $100 \mathrm{mM} \mathrm{KCl}, 10 \mathrm{mM} \mathrm{NaCl}, 10 \mathrm{mM}$ Hepes, $1 \mathrm{mM}$ EDTA, $0.1 \mathrm{mM}$ dithiothreitol, $1 \mathrm{mM}$ PMSF, and $10 \mu \mathrm{g} / \mathrm{ml}$ chymostatin (pH 7.3). Column-running buffer (CRB) consisted of $500 \mathrm{mM}$ $\mathrm{NaCl}, 50 \mathrm{mM}$ Hepes, $5 \%$ (vol/vol) glycerol, $1 \mathrm{mM}$ EDTA, $0.1 \mathrm{mM}$ dithiothreitol, $0.02 \%$ azide ( $\mathrm{pH} 7.3$ ), and either octyl glucoside or Triton $\mathrm{X}-100$ in the amounts described in the text. Sucrose solutions consisted of the appropriate amount of sucrose dissolved in $100 \mathrm{mM}$ $\mathrm{KCl}, 10 \mathrm{mM} \mathrm{NaCl}, 10 \mathrm{mM}$ Hepes, $1 \mathrm{mM}$ EDTA, and $0.1 \%$ Triton $\mathrm{X}-100$ (pH 7.3).
Preparation of cytochrome b-enriched neutrophil membranes. Purified granulocyte polymorphonuclear neutrophilic leukocytes (PMN) (> 95\% PMN) were obtained from peripheral blood by scaling up the procedure of Henson and Oades (22) to accommodate $1 \mathrm{U}$ of blood. Typically, $1 \mathrm{U}$ of blood yielded between 0.8 and $1.2 \times 10^{9}$ neutrophils. Red cells were lysed by two treatments with isotonic ammonium chloride. The resultant neutrophil suspensions from different units were pooled and treated with diisopropylfluorophosphate (DFP) (24) to inactivate serine esterases. After two washes in DPBS the cells were resuspended at $10^{8}$ cells $/ \mathrm{ml}$ in $\mathrm{DPBS}^{+}$to which catalase $(500 \mathrm{U} / \mathrm{ml})$ and superoxide dismutase $(30 \mathrm{U} / \mathrm{ml})$ were added.

The resuspended cells were then treated with $2 \mu \mathrm{g} / \mathrm{ml}$ dihydrocytochalasin B and allowed to warm to $37^{\circ} \mathrm{C}$ for $7 \mathrm{~min}$. Degranulation was achieved by stimulation with $1 \mu \mathrm{M} N$-formyl-Met-Leu-Phe for $3 \mathrm{~min}$, after which the reaction terminated with 4 vol of ice-cold DPBS and centrifuged at $1,300 \mathrm{~g}$ for $15 \mathrm{~min}$. After washing the cells twice with DPBS, they were disrupted by nitrogen cavitation ( 400 psi for $15 \mathrm{~min}$ at $4^{\circ} \mathrm{C}$ ) in a modified relaxation buffer originally described by Borregaard and Tauber (25) at $10^{8}$ cells $/ \mathrm{ml}$. The cavitate was collected in a tube containing one-tenth the starting volume of nitrogen cavitation buffer plus $12.5 \mathrm{mM}$ EGTA and separated into a low-speed $(1,000 \mathrm{~g}, 5$ $\mathrm{min}$ ) supernatant and foam/pellet residue. The foam/pellet residue was rehomogenized by 10 strokes in a glass Dounce tissue homogenizer and again fractionated into a low-speed supernatant and pellet residue.

The low-speed supernatant fractions were pooled and centrifuged in a $60 \mathrm{Ti}$ rotor (Beckman Instruments, Inc., Fullerton, CA) for $45 \mathrm{~min}$ at $45,000 \mathrm{rpm}$ and $4^{\circ} \mathrm{C}$. The resultant yellowish pellets were carefully transferred to a glass Dounce homogenizer and resuspended in membrane resuspension buffer (MRB) at a protein concentration of 3-5 $\mathrm{mg} / \mathrm{ml}$. The resuspended membranes were stored at $-70^{\circ} \mathrm{C}$ until further use.

Detergent solubilization of cytochrome $b$. After thawing on ice, the membranes were treated with $1 \mathrm{M}$ salt by adding $1 \mathrm{ml}$ of $5 \mathrm{M} \mathrm{NaCl}$ per $4 \mathrm{ml}$ of the membrane suspension, thoroughly mixing and then centrifuging the mixture at $100,000 \mathrm{~g}$ for $30 \mathrm{~min}\left(4^{\circ} \mathrm{C}\right)$. The clear yellow $100,000 \mathrm{~g}$ supernatant was discarded, and the yellow pellet was resuspended in a small volume of MRB with the aid of a glass Dounce tissue homogenizer. Complete solubilization of the cytochrome $b$ was achieved by adjusting the protein concentration to $1-2 \mathrm{mg} / \mathrm{ml}$ with MRB and adding octylglucoside to make a final detergent concentration of $2 \%(w t / v o l)$. The detergent solution was mechanically stirred by a vortex mixer and kept on ice for $30 \mathrm{~min}$ and then centrifuged at $100,000 \mathrm{~g}\left(\mathrm{r}_{\mathrm{av}}\right)$ for $30 \mathrm{~min}$ at $4^{\circ} \mathrm{C}$ in a $50 \mathrm{Ti}$ or $60 \mathrm{Ti}$ rotor (Beckman Instruments, Inc.). The $2 \%$ octylglucoside $100,000 \mathrm{~g}$ supernatant was then used for further purification of cytochrome $b$.

Affinity chromatography. After detergent solubilization, the cytochrome $b$ was further purified by affinity chromatography utilizing wheat germ agglutinin-conjugated Sepharose 4B (WGA-4B). Wheat germ agglutinin (WGA) was conjugated to Sepharose $4 B$ at $3 \mathrm{mg}$ of WGA per gram of dried cyanogen bromide-activated Sepharose as described by the provider except that $25 \mathrm{mM} N$-acetyl glucosamine was included in the conjugation buffer. To optimize binding of cytochrome $b$ to the immobilized WGA, the detergent concentration had to be lower than its critical micellar concentration (0.8\%). A binding and elution protocol was devised as follows: three parts MRB were mixed with one part of the octylglucoside containing $100,000 \mathrm{~g}$ supernatant to reduce the detergent concentration to $0.5 \%(\mathrm{wt} / \mathrm{vol})$. WGA-4B was then added at a ratio of $1.7 \mathrm{ml}$ of affinity beads per $4 \mathrm{ml}$ of diluted extract and rotated end over end at $4^{\circ} \mathrm{C}$ overnight. After washing the protein-bound affinity matrix with $0.5 \%$ octylglucoside in MRB, the cytochrome $b$ was eluted with two bed volumes of MRB plus $200 \mathrm{mM} N$-acetylglucosamine, $200 \mu \mathrm{g} / \mathrm{ml}$ chitobiose, $0.4 \mathrm{M} \mathrm{NaCl}$, and $0.2 \%$ Triton $\mathrm{X}-100$ for $1 \mathrm{~h}$ at room temperature. The affinity matrix was then reincubated for $30 \mathrm{~min}$ at room temperature with one bed volume of the same buffer. The eluates were pooled and concentrated 10-fold with an Amicon PM 10 ultrafilter (Danvers, MA) (temperature, $\left.4^{\circ} \mathrm{C}\right)$. 
The concentrated WGA-4B eluate was then diluted 10-fold with 10 mM Hepes, $0.1 \%$ Triton $\mathrm{X}-100, \mathrm{pH} 7.4$, to reduce the salt concentration to $50 \mathrm{mM}$. It was then pumped through a 5-ml column of heparin ultrogel at $15 \mathrm{ml} / \mathrm{h}$ and $4^{\circ} \mathrm{C}$. After washing with 5 column volumes of $40 \mathrm{mM} \mathrm{NaCl}, 10 \mathrm{mM} \mathrm{KCl}, 1 \mathrm{mM}$ EDTA, $10 \mathrm{mM}$ Hepes, $\mathrm{pH} 7.4$, and $0.2 \%$ Triton $\mathrm{X}-100$, the orange-colored cytochrome was eluted at a flow rate of $20 \mathrm{ml} / \mathrm{h}$ with a $150-\mathrm{ml}$ linear gradient of salt starting with wash buffer and increasing to $1.5 \mathrm{M} \mathrm{NaCl}$ made up in MRB with $0.2 \%$ Triton X-100. $1 \mathrm{mM}$ PMSF and $10 \mu \mathrm{g} / \mathrm{ml}$ chymostatin were included in the salt gradient for protease inhibition.

Velocity sedimentation of cytochrome $b$ in sucrose gradients. Final purification of the cytochrome $b$ was achieved by velocity sedimentation in sucrose gradients. Linear sucrose gradients (5-20\% wt/vol, 5 $\mathrm{ml}$ ) containing $0.1 \%(\mathrm{wt} / \mathrm{vol})$ Triton X-100 were constructed and fractionated in a manner similar to that described by Clarke (26). The heparin ultrogel eluate was concentrated to a final cytochrome concentration of 2-4 $\mu \mathrm{M}$ using Centricon 30 microconcentrators (Amicon, Inc., Danvers, MA) and $0.325 \mathrm{ml}$ overlaid on each sucrose gradient. The gradients were centrifuged at $45,000 \mathrm{rpm}$ for $20 \mathrm{~h}$ in an SW 50.1 rotor (Beckman Instruments, Inc.) at $4^{\circ} \mathrm{C}$. Fractions of $0.35-0.375 \mathrm{ml}$ were collected from the top with a densiflow pump (Buchler Instruments Inc., Fort Lee, NJ).

Electrophoresis. SDS gel electrophoresis was carried out at room temperature in polyacrylamide slab gels containing $0.1 \%$ (wt/vol) SDS (27). Protein samples were mixed with an equal volume of sample buffer and boiled for 3-4 min. Sample buffer consisted of 1 part $10 \%$ (wt/vol) SDS in $\mathrm{H}_{2} \mathrm{O}, 1$ part $0.5 \mathrm{M}$ Tris base, $\mathrm{pH} \mathrm{6.8,1}$ part glycerol, and $500 \mathrm{mM}$ 2-mercaptoethanol. In some experiments, sample buffer contained $8 \mathrm{M}$ urea. The electrophoretic mobility of protein samples was compared with the mobility of standard proteins. Proteins were visualized on slab gels by first staining for $30 \mathrm{~min}$ with $0.125 \%$ Coomassie Blue G 250 in 50\% methanol, 10\% acetic acid. Gels were then destained in 25\% isopropanol and $10 \%$ acetic acid and hydrated in $\mathrm{H}_{2} \mathrm{O}$ overnight with several changes of $\mathrm{H}_{2} \mathrm{O}$. Hydrated gels were then silver stained under basic conditions as described by Wray et al. (28). For comparative purposes some polyacrylamide gels were silver stained under acidic conditions as described by Merril et al. (29).

Deglycosylation experiments. Deglycosylation studies were performed on purified ${ }^{125} \mathrm{I}$-labeled cytochrome $b$. Peak sucrose gradient fractions were iodinated with immobilized chloramine T (Iodobeads) as described by the provider. Unbound iodine was removed by centrifugation through a 3-ml column of Sephadex G-25 equilibrated with column running buffer plus $0.1 \%$ Triton $\mathrm{X}-100$.

Removal of $N$-linked carbohydrate was done with peptide: $N$-glycosidase $\mathrm{F}$ as described by the provider except that incubations were done in column running buffer (pH 7.4) plus $5 \%$ (wt/vol) sucrose, 2 mM PMSF, $10 \mathrm{mM}$ 1,10-phenanthroline, and $5 \mathrm{mM}$ EDTA. Deglycosylation was complete in $24 \mathrm{~h}$ at room temperature. Beta-elimination experiments were performed to investigate the possibility of $O$ linked carbohydrate (30). ${ }^{125}$ I-labeled cytochrome $b$ was incubated in the presence of $0.1 \mathrm{~N} \mathrm{NaOH}$ for up to $24 \mathrm{~h}$ at $4^{\circ} \mathrm{C}$. Samples were then neutralized with an appropriate volume of $0.3 \mathrm{~N} \mathrm{HCl}$. As a positive control, parallel beta elimination and $N$-glycosidase $\mathrm{F}$ studies were performed in the presence of 5-10 $\mu \mathrm{g}$ fetuin $(31,32)$. The electrophoretic mobility of reduced and treated samples was compared with that of reduced untreated samples.

Biochemical assays. Cytochrome $b$ was quantitated by reduced minus oxidized difference spectroscopy on a Cary 219 dual-beam spectrophotometer (Varian, Inc., San Jose, CA) assuming an extinction coefficient of $29.3 \mathrm{mM}^{-1} \mathrm{~cm}^{-1}$. (20). Samples were reduced by the addition of $2 \mu \mathrm{l}$ of a $1.0 \mathrm{M}$ solution of sodium dithionite made up in $\mathrm{H}_{2} \mathrm{O}$ immediately before use.

Protein was measured by the Bradford method (33), the BCA method as described by Pierce, Inc., and by fluorescence after conjugation of free amines with fluorescamine (34) using bovine serum albumin as a protein standard.

Cross-linking studies. Samples were treated with nonreversible homobifunctional cross-linking agent disuccinimidyl suberate (DSS) (temperature, $20^{\circ} \mathrm{C}$ ) as follows. To $100-200 \mu$ l of purified cytochrome $b(\sim 1 \mu \mathrm{M})$ from concentrated peak sucrose gradient fractions containing $1 \%(w t / v o l)$ Triton X-100, DSS was added $(100 \mathrm{mM}$ in dimethylsulfoxide [DMSO]) to a final concentration of $0.25 \mathrm{mM}(0.25 \%$ DMSO). At different times aliquots were removed, and the reaction was terminated by the addition of $0.25 \mathrm{M}$ glycine ( $\mathrm{pH} 7.4$ ) to a final concentration of $20 \mathrm{mM}$. Samples were then mixed with an equal volume of sample buffer and subjected to SDS-PAGE as described in the previous section. SDS gel profiles of cross-linked samples were compared with the uncross-linked controls treated with DMSO only.

Production of rabbit antibodies to cytochrome $b$. Juvenile New Zealand White rabbits $(1.5 \mathrm{~kg})$ were immunized with either cytochrome $b$-enriched eluate from immobilized heparin or purified cytochrome $b$. The initial immunization mixture consisted of 20-30 $\mu \mathrm{g}$ protein in $1 \mathrm{ml}$ of saline plus $1 \mathrm{ml}$ of Complete Freund's Adjuvant. The emulsified protein-adjuvant mixture was injected in 10-20 sites intradermally just lateral to the rabbit's spine.

The next two immunizations were at 10-d intervals and consisted of the same type of intradermal injection but with an emulsified mixture consisting of $10 \mu \mathrm{g}$ of protein in $0.5 \mathrm{ml}$ saline plus $0.5 \mathrm{ml}$ of Incomplete Freund's Adjuvant. Rabbits were then immunized at 2-wk intervals with the same mixture of protein and incomplete adjuvant, and antibody titers were monitored by enzyme-linked immunosorbant assay (ELISA). Once antibody titers were sufficiently elevated, blood was obtained from the central artery of the ear in 50-75 ml quantities, depending on the size of the animal. Animals with elevated antibody titers were maintained on a schedule consisting of reimmunizations every 2-4 wk followed by bleeding 1 wk after the previous immunization.

Detection of antibodies. To monitor antibody levels in the rabbits, we developed an ELISA. To round bottom microtiter plates we added $50 \mu \mathrm{l} \mathrm{of} \mathrm{a} 50-\mu \mathrm{g} / \mathrm{ml}$ solution of poly-L-lysine (mol wt 14,000$)$ in DPBS(-) and incubated for $30 \mathrm{~min}$ at $37^{\circ} \mathrm{C}$. Then we added $50 \mu \mathrm{l}$ of a mixture containing $150-250 \mathrm{ng}$ cytochrome $b$ in $25 \mathrm{mM} \mathrm{NaCl}, 10 \mathrm{mM}$ Hepes, $\mathrm{pH} 7.4$, and $0.02 \%$ Triton X-100 to the washed microtiter wells. The plate was then incubated for at least $60 \mathrm{~min}$ at $37^{\circ} \mathrm{C}$ and washed with DPBS(-). The microtiter wells were then treated with $100 \mu \mathrm{l}$ of $2 \%$ bovine serum albumin in DPBS for $15 \mathrm{~min}$ at $37^{\circ} \mathrm{C}$. After shaking the wells dry, $50 \mu$ l of primary antibody diluted in $2 \%$ BSA/DPBS(-) was added and incubated for either $60 \mathrm{~min}$ at $37^{\circ} \mathrm{C}$ or overnight at $4^{\circ} \mathrm{C}$. The wells were then washed four to six times with DPBS $(-)$. The secondary antibody mixture consisted of $50 \mu \mathrm{l}$ of $1 \mu \mathrm{g} / \mathrm{ml}$ of peroxidase-conjugated goat anti-rabbit IgG in 2\% BSA/DPBS(-) and was incubated for $30 \mathrm{~min}$ at $37^{\circ} \mathrm{C}$. After washing each well five or six times with DPBS(-), $50 \mu \mathrm{l}$ of colorimetric substrate which consisted of 0.5 $\mathrm{mM}$ ABTS and $5 \mathrm{mM} \mathrm{H}_{2} \mathrm{O}_{2}$ in $0.1 \mathrm{M}$ citrate buffer, $\mathrm{pH} 4.2$, was added. After sufficient color development (10-30 $\mathrm{min})$ the reaction was stopped with $10 \mu \mathrm{l}$ of $10 \%$ SDS, and the absorbance read at $414 \mathrm{~nm}$ in an automated microtiter plate scanner (Bio-Tek Instruments, Inc., Burlington, VT)

Immunoprecipitation studies. The ability of the rabbit antibodies to react with detergent-solubilized cytochrome $b$ was investigated by incubation of concentrated eluate from immobilized heparin with various amounts of immune or preimmune $\mathrm{IgG}$ for $1 \mathrm{~h}$ at $20^{\circ} \mathrm{C}$ followed by sedimentation for $10 \mathrm{~h}$ in $5-20 \%$ (wt/vol) sucrose gradients containing $1 \%$ Triton $\mathrm{X}-100$ as described in a previous section. Fractions of $0.35 \mathrm{ml}$ were collected from sucrose gradients with a densiflow pump (Buchler Instruments Inc.). Sucrose gradient fractions were then diluted with $0.25 \mathrm{ml}$ of DPBS(-) and assayed for cytochrome $b$, as described in the previous sections.

Western blotting experiments. Electrophoretic transfer of proteins from SDS-polyacrylamide slab gels onto nitrocellulose was performed according to Towbin et al. (35). Protein-bound nitrocellulose strips were first incubated for $1 \mathrm{~h}$ in saturating buffer consisting of $10 \%$ goat serum and 3\% BSA in $0.5 \mathrm{M} \mathrm{NaCl}$ and $10 \mathrm{mM}$ Hepes, pH 7.4. The nitrocellulose strips were then incubated overnight at $4^{\circ} \mathrm{C}$ with $1 \mu \mathrm{g}$ per $\mathrm{ml}$ of rabbit IgG in DPBS(-) plus $3 \%$ goat serum, $1 \%$ BSA, and $0.2 \%$ Tween 20. After rinsing the nitrocellulose five times with wash buffer 
consisting of $0.25 \mathrm{M} \mathrm{NaCl}, 10 \mathrm{mM}$ Hepes, $0.2 \%$ Tween 20 , pH 7.4, the strips were then incubated for $1 \mathrm{~h}$ at $20^{\circ} \mathrm{C}$ with $1 \mu \mathrm{g} / \mathrm{ml}$ of peroxidaseconjugated goat anti-rabbit IgG in DPBS(-) plus 3\% goat serum, $1 \%$ BSA, and $0.2 \%$ Tween 20 . Again after rinsing five times with wash buffer, the nitrocellulose strips were color developed for 5-30 min in a solution of developer consisting of $30 \%$ methanol, $0.5 \mathrm{mg} / \mathrm{ml}$ peroxidase color developer (4-chloro-1-napthol) (Bio-Rad Laboratories), and $5 \mathrm{mM} \mathrm{H}_{2} \mathrm{O}_{2}$ in $0.25 \mathrm{M} \mathrm{NaCl}, 10 \mathrm{mM}$ Hepes, $\mathrm{pH}$ 7.4. The reaction was terminated by the transfer of nitrocellulose strips to distilled water.

\section{Results}

The purification of neutrophil cytochrome $b$. We designed a scheme for purification of cytochrome $b$ from human granulocytes based on what was known about its colocalization with both the specific granules and plasma membrane (36-38) and preliminary evidence about its properties as a putative integral membrane glycoprotein $(17,23,37)$ and our own unpublished observations (Parkos, C. A., A. J. Jesaitis, and R. A. Allen).

A summary of the specific activities and recoveries of cytochrome $b$ at various stages of purification is shown in Table I. The membranes used for solubilization offered several advantages over solubilization of whole cells. First, degranulation and nitrogen cavitation mobilized the internal pool of cytochrome $b$ to the plasma membrane while eliminating soluble proteins and proteases. Second, using the cavitation buffer described, recovery of membranes from the disrupted cells was 90-95\%, based on partitioning of cytochrome between the low-speed supernatants and pellets. Third, treatment of membranes with $1 \mathrm{M} \mathrm{NaCl}$ removed $15-20 \%$ of the total contaminating peripheral membrane protein while increasing the extractability of the cytochrome $b$ by $20 \%$. Therefore, the preparation of salt-washed membranes from degranulated cells produced a significantly enriched and more extractable preparation with high yields of cytochrome $b$. This preparation was depleted of granular proteases and relatively free of cytosolic and peripheral membrane protein contamination. SDS gel electrophoresis of the preparation at each stage of purification is shown in Fig. 1.

We tested the ability of numerous detergents to solubilize cytochrome $b$ from membranes and found octylglucoside and Triton X-100 to be the most efficient. Octylglucoside was found to extract virtually $100 \%$ of the cytochrome under the conditions described and offered the advantage of having a high critical micellar concentration. As shown in Table I, the detergent extract had a mean cytochrome $b$ content of 0.96 $\mathrm{nmol} / \mathrm{mg}(\sim 0.26 \mu \mathrm{M}$ cytochrome $b)$ with a protein concentration of $0.2-0.25 \mathrm{mg} / \mathrm{ml}$.

We performed preliminary tests on whole cells to measure the ability of lectins to induce cross-linking of cytochrome $b$ and hence inhibit detergent extractability. It was discovered that treatment of cells with wheat germ agglutinin caused a $50 \%$ reduction in the extractability of cytochrome $b$. The solubilized cytochrome $b$ was found to reproducibly bind to WGA-4B. This binding could be completely inhibited by 100 $\mathrm{mM} N$-acetylglucosamine. To obtain $>90 \%$ binding of the cytochrome to WGA-4B, the detergent concentration had to be less than its critical micellar concentration. For elution of the bound cytochrome, a combination of competing sugars, high salt, and greater than critical micellar concentrations of detergent were necessary to obtain good recoveries (65-85\%). The recovery of cytochrome $b$ was also sensitive to the density of wheat germ agglutinin on beads, with $1 \mathrm{mg}$ lectin/ml of beads being the optimal density of several tested. Elution of the cytochrome in Triton X-100 rather than octylglucoside was necessary to optimize yields in the subsequent purification steps. As shown in Table I, the WGA-4B eluate had a cytochrome $b$ content of $2.58 \mathrm{nmol}$ per $\mathrm{mg}$ protein, which represents a threefold enrichment over the 100,000- $g$ octyl glucoside extract. Elution of bound cytochrome $b$ with a gradient of $N$-acetyl glucosamine or chitobiose offered no advantages because the protein slowly eluted over the entire gradient, and the specific activity was the same as that from batch elution.

For optimized binding of the cytochrome to immobilized heparin, the detergent had to be in excess of the critical micellar concentration in a low-ionic strength buffer. The WGA-4B eluate was concentrated and then diluted because of unsatisfactory $(40 \%)$ losses when dialysis was performed. Fig. 2 shows the elution profile of cytochrome $b$ from heparin ultrogel. The cytochrome eluted as a single sharp peak in a gradient of $\mathrm{NaCl}$, whereas the protein profile revealed a shoulder comprised mainly of a higher molecular weight species, $M_{r} 170,000$. As shown in Table I, the heparin eluate was three to fourfold enriched in cytochrome, and Fig. 1 shows the appearance of

Table I. Purification of Cytochrome b

\begin{tabular}{|c|c|c|c|}
\hline Fraction & Specific activity & Recovery & $\begin{array}{l}\text { Recoveries from } 6 \mathrm{U} \text { of blood } \\
\text { or } \sim 6 \times 10^{9} \text { granulocytes }\end{array}$ \\
\hline & nmol/mg protein & $\%$ & nmol \\
\hline DFP-treated granulocytes & $0.074 \pm 0.002(0.1)$ & - & $15 \pm 2.4 \quad(20.3)$ \\
\hline Cytochrome $b$-enriched membranes & $0.22 \pm 0.11 \quad(0.3)$ & $90-95$ & $13.9 \pm 2.1 \quad(18.8)$ \\
\hline $2 \%$ octylglucoside $100,000 \mathrm{~g}$ supernatant & $1.1 \pm 0.37$ & $90-95$ & $13.9 \pm 2.1 \quad(18.8)$ \\
\hline Wheat germ agglutinin-Sepharose eluate & $2.58 \pm 0.37 \quad(3.5)$ & $65-75$ & $10.7 \pm 2.0 \quad(14.5)$ \\
\hline Heparin ultrogel eluate & $8.85 \pm 1.8 \quad(12)$ & $40-55$ & $6.3 \pm 0.88(8.6)$ \\
\hline Peak sucrose gradient fractions & $19.2 \pm 2.9$ & $20-30$ & $3.6 \pm 0.66(4.9)$ \\
\hline
\end{tabular}

The specific contents and recoveries of cytochrome $b$ at various stages of purification as described in Methods. Values are reported \pm SD. Cytochrome $b$ was quantitated by reduced-minus-oxidized difference spectroscopy as described in Methods assuming an extinction coefficient $(559-540 \mathrm{~nm})$ of $29.3 \mathrm{mM}^{-1} \mathrm{~cm}^{-1}$ (27). Peak sucrose gradient fractions refer to the peak three fractions containing 50-60\% of the applied cytochrome $b$. Specific activities were based on BSA as a standard. Recoveries are based on starting cell contents. For comparative purposes, values in parentheses refer to computations based on an extinction coefficient of $21.6 \mathrm{mM}^{-1} \mathrm{~cm}^{-1}$ (15). 
A

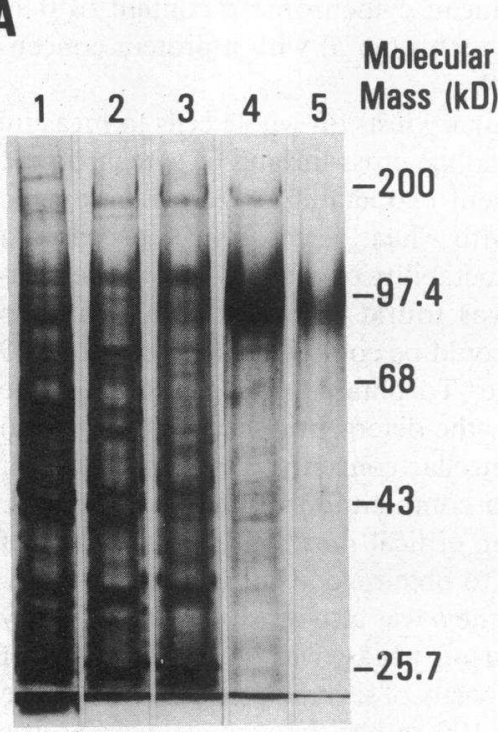

B

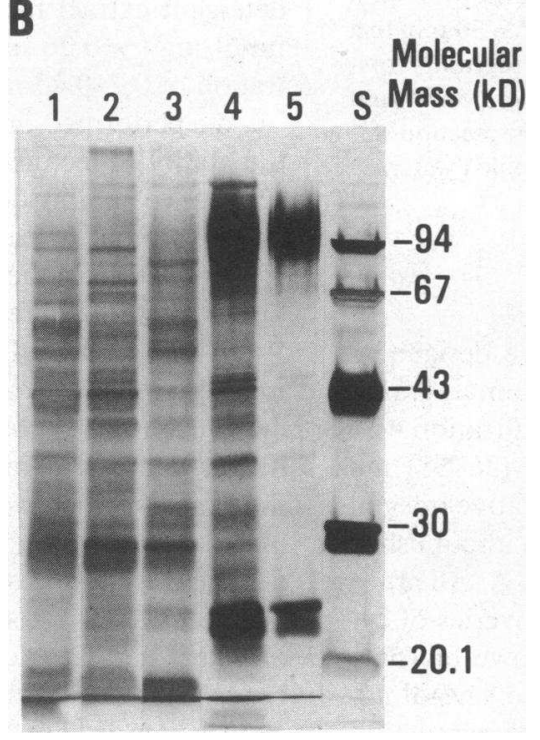

Figure 1. Analysis of the purification of cytochrome $b$ by SDS-PAGE. Protein samples from various stages of the purification procedure were subjected to SDS-PAGE on $8 \%(A)$ and $11 \%(B)$ (wt/vol) polyacrylamide gels containing $0.1 \%$ SDS and stained with silver as described in Methods.

Lane $1,2.5 \mu \mathrm{g}$ protein in $(A)$ and $1.5 \mu \mathrm{g}$ protein in $(B)$ from membranes enriched in cytochrome $b$.

Lane $2,2.5 \mu \mathrm{g}$ protein in $(A)$ and $1.5 \mu \mathrm{g}$ protein in $(B)$ from the $2 \%$ octyl glucoside, $100,000 \mathrm{~g}$ supernatant. Lane 3, $2.5 \mu \mathrm{g}$ protein in $(A)$ and $1.5 \mu \mathrm{g}$ of protein in $(B)$ of eluate from WGA-4B. Lane 4, both panels, $1.5 \mu \mathrm{g}$ protein from heparin-Ultrogel eluate. Lane 5 , both panels, $0.75 \mu \mathrm{g}$ protein from peak sucrose gradient fractions containing purified cytochrome $b .(A)$, Molecular mass of standard proteins is listed to the right, including myo$\sin (200 \mathrm{kD})$, phosphorylase B (97.4 kD), BSA (68 $\mathrm{kD}$ ), ovalbumin (43 kD), and $\alpha$-chymotrypsinogen $(25.7 \mathrm{kD})$. (B) Lane marked $S$ represents $1 \mu \mathrm{g}$ each of standard with molecular mass listed to the right. Standards in $(B)$ include phosphorylase (94 $\mathrm{kD})$, BSA (67 kD), ovalbumin (43 kD), carbonic anhydrase $(30 \mathrm{kD})$, and soybean trypsin inhibitor (20.1 kD). major protein staining bands with values of $M_{r} 91,000$ and $M_{r}$ 22,000 along with several other protein bands.

As shown in Fig. 3, final purification was achieved by sedimentation in sucrose density gradients. The concentrated heparin eluate was sedimented for $20 \mathrm{~h}$ in $5-20 \%$ (wt/vol) sucrose gradients, which separated $50-70 \%$ of cytochrome $b$ spectral activity from a major protein contaminant of $170,000 \mathrm{D}$. The results shown in Table I indicate that the pooled peak sucrose gradient fractions were enriched in cytochrome $b \sim 260$-fold

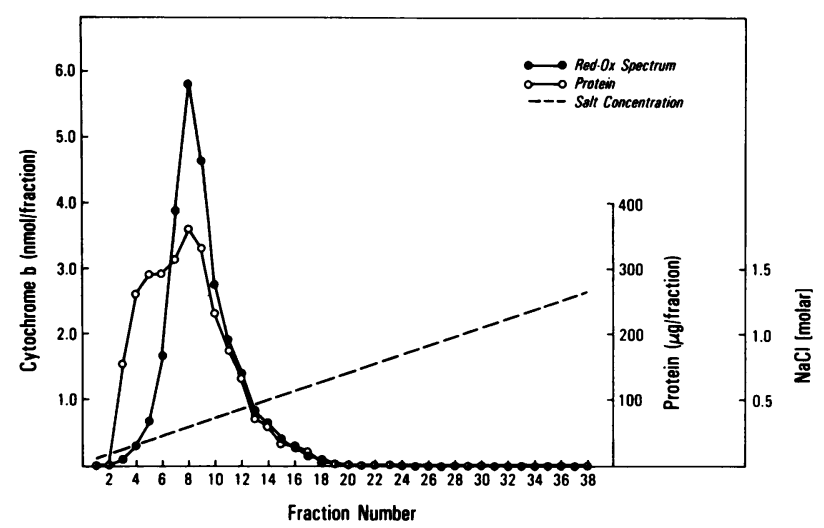

Figure 2. Elution of cytochrome $b$ from heparin ultrogel. Eluate from WGA-4B containing $35.8 \mathrm{nmol}$ of cytochrome $b$ was pumped through a 5-ml column of heparin ultrogel as described in Methods. After washing the column with low-ionic strength buffer containing $0.2 \%$ Triton X-100, the cytochrome was eluted at a rate of $20 \mathrm{ml} / \mathrm{h}$ with a 150-ml gradient of $\mathrm{NaCl}$ increasing from 0.04 to $1.5 \mathrm{M}$. Nanomoles cytochrome $b$ (solid circles) and micrograms protein (open circles) per fraction are plotted against fraction number. Salt concentration (dashed line) is also plotted against fraction number. $\mathrm{Cy}-$ tochrome $b$ was quantitated as described in Methods and the recovery was $25.5 \mathrm{nmol}$ or $\mathbf{7 1 . 2 \%}$. Protein was assayed by the BCA protein assay kit as described by Pierce Chemical Co., using BSA as a standard. One of three experiments. over starting cell material with an overall yield between 20 and $30 \%$. The composition of these fractions was analyzed by SDS-PAGE. This analysis is shown in Figs. $1 B$ and $3 B$ and reveals two protein-staining bands. These two bands were also present when cytochrome $b$ purification was performed on purified plasma membranes obtained from unstimulated cells (not shown), suggesting that their copurification was not the result of stimulation of cytochalasin-treated cells with formyl polypeptides. The unusual staining pattern of the smaller protein component seen in Fig. $1 B$ is most likely an artefact of our gel system and not due to overlapping polypeptides of similar molecular weight. Similar staining is seen on the low molecular weight components of our protein molecular weight standards (Fig. 1, lane $S$ ). We were unable to resolve two protein bands on larger SDS polyacrylamide gels.

Relative molecular weight estimates of the larger species were found to increase with increasing polyacrylamide concentration in SDS gels. On $8 \%$ (wt/vol) SDS polyacrylamide slab gels, the relative molecular weight of the larger species was estimated at $91,000 \pm 3,000$, whereas electrophoresis on $11 \%$ (wt/vol) gels revealed a slightly increased $M_{r}$ of $97,000 \pm 3,000$. We have assigned the value of 91,000 as the relative molecular weight of the larger protein species to be consistent. The relative molecular weight of the smaller component was not variable and was determined to be $22,000 \pm 3,000$ on both $11 \%$ and $15 \%$ (wt/vol) SDS polyacrylamide gels. The reduced minusoxidized absorbance difference spectrum of the purified cytochrome $b$ had alpha, beta, and Soret absorbances of 558.7, 528 , and 426.5 , which are in agreement with those reported by others $(20,23)$.

Analysis of glycosylation of cytochrome $b$. Our preliminary experiments on whole cells and those on the detergent extracts of membranes which indicated that cytochrome $b$ bound to lectins suggested that cytochrome $b$ was a glycoprotein or closely associated with one. In addition, recent analyses by Harper et al. (19) indicated that the neutrophil cytochrome $b$ from human myelogenous leukemia patients $\left(M_{r} 68,000-\right.$ 

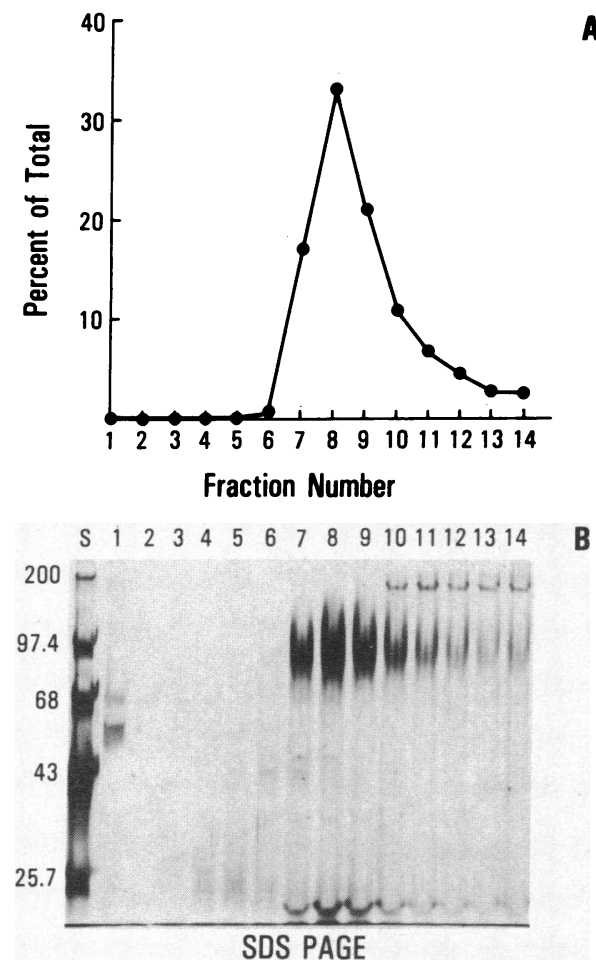

Figure 3. Final purification of cytochrome $b$ by sucrose density gradient velocity sedimentation. $0.35 \mathrm{ml}$ of concentrated eluate from immobilized heparin with a cytochrome $b$ concentration of $2.5 \mu \mathrm{M}$ was sedimented for $20 \mathrm{~h}$ in 5-20\% (wt/vol) linear sucrose density gradients containing $0.1 \%$ Triton $\mathrm{X}-100$ and then fractionated as described in Methods. $(A)$ Percent total recovered cytochrome $b$ spectral activity is plotted against fraction number where fraction 1 represents the top of the gradient. Total recovered spectral activity was $90-100 \%$ of that applied to the gradients. $(B) 25 \mu$ of each corresponding sucrose gradient fraction shown in $(A)$ was mixed with an equal volume of sample buffer and subjected to SDS-PAGE on a $9 \%$ (wt/vol) polyacrylamide gel and silver stained as described in Methods. Lane $S$ represents standard proteins with their molecular mass listed to the left. Standards included myosin $(200 \mathrm{kD})$, phosphorylase B (97.4 kD), BSA (68 kD), ovalbumin (43 kD), and $\alpha$-chymotrypsinogen $(25.7 \mathrm{kD})$. Profile shown above is typical of $>20 \mathrm{ex}-$ periments.

78,000 , reference $23 ; M_{r} 72,000-90,000$, reference 19) $\mathrm{mi}$ grated with increased mobility by SDS-PAGE after treatment with endoglycosidase F. Estimates from carbohydrate analyses of purified preparations indicated that $15 \%$ of the mass of their preparation was carbohydrate. However, because of uncertainties in the reported SDS-PAGE mobilities and glycoprotein contaminants present in their preparation, an independent analysis of the glycosylation of cytochrome $b$ was necessary.

Glycoproteins often exhibit anomalous behavior when subjected to SDS-PAGE $(39,40)$. Thus, to obtain an estimate of the molecular weight of the polypeptide portion of cytochrome $b$, the effect of deglycosylation on its relative molecular weight was studied. Purified cytochrome $b$ was iodinated as described in the methods, which by SDS-PAGE and subsequent autoradiography revealed two bands of $M_{r} 91,000$ and 22,000. As shown in Fig. 4, beta elimination conditions that decreased the relative molecular weight of fetuin controls had a minimal effect on the mobility of the $M_{r}-91,000$ protein

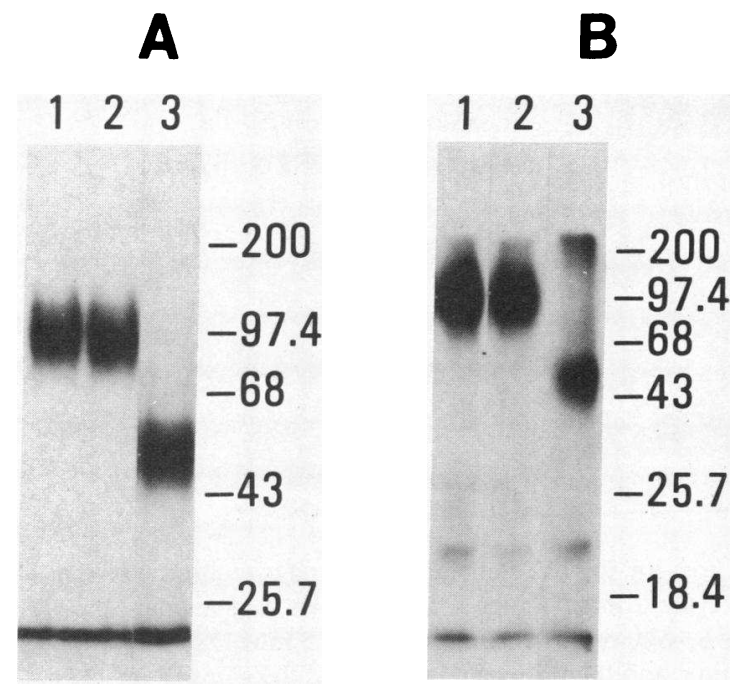

Figure 4. Autoradiograms demonstrating effect of deglycosylation on $\mathbf{M}_{\mathrm{r}}$ of [ $\left.{ }^{125} \mathrm{I}\right]$ cytochrome $b$. Deglycosylation experiments were performed on [ $\left.{ }^{125} \mathrm{I}\right]$ cytochrome $b$ as described in Methods. 10,000 cpm of labeled protein was subjected to reduced SDS gel electrophoresis on $8 \%(A)$ and $11 \%(B)(\mathrm{wt} / \mathrm{vol})$ polyacrylamide gels as described in Methods. Gels were fixed, dried, and subjected to autoradiography for $48 \mathrm{~h}$. Lane 1, both panels, untreated control cytochrome $b$. Lane 2 , both panels, cytochrome $b$ after $24 \mathrm{~h}$ of beta-elimination in $0.1 \mathrm{~N}$ $\mathrm{NaOH}$ at $4^{\circ} \mathrm{C}$. Lane 3 , both panels, cytochrome $b$ after peptide: $N$ glycosidase $\mathrm{F}$ treatment for $24 \mathrm{~h}$ at $20^{\circ} \mathrm{C}$. In both panels, the molecular masses in kilodaltons of protein standards are included to the right of lane, including myosin $(200 \mathrm{kD})$, phosphorylase $\mathrm{B}(97.4 \mathrm{kD})$, BSA (68 kD), ovalbumin (43 kD), -chymotrypsinogen (25.7 kD), and beta-lactoglobulin $(18.4 \mathrm{kD})$.

band. Treatment with peptide: $N$-glycosidase $F$, on the other hand, caused a large increase in the electrophoretic mobility of the $M_{r}-91,000$ band, which suggests the presence of significant amounts of $N$-linked carbohydrate. A single band with an $\mathbf{M}_{\mathbf{r}}$ 48,000-50,000 appeared after endoglycosidase treatment along with total disappearance of the $M_{r}-91,000$ band. Neither treatment had any effect on the electrophoretic mobility of the $\mathrm{M}_{\mathrm{r}}-22,000$ band.

Cross-linking studies. To investigate whether the two polypeptides of $M_{r} 91,000$ and 22,000 present in purified cytochrome $b$ preparations are indeed closely associated, crosslinking studies were performed. Purified cytochrome $b$ at an approximate concentration of $0.75 \mu \mathrm{M}$ was exposed to the homobifunctional cross-linking reagent DSS under conditions that do not cross-link control standard proteins. As shown in Fig. 5, this exposure resulted in a time-dependent decrease in the staining density of the $M_{r}-91,000$ and $M_{r}-22,000$ protein constituents with the appearance of a new band having a lower electrophoretic mobility. This new band had a value of $\mathbf{M}_{\mathbf{r}}$ $120,000-135,000$ on the $11 \%$ (wt/vol) SDS-polyacrylamide gel shown in Fig. 6. No additional bands were produced either in the cytochrome-containing sample, or in the more concentrated protein standard solution. Because there was no detectable effect of cross-linking on spectra or the sedimentation characteristics shown in Fig. 3, a close association is suggested between the 91,000 - and 22,000-D polypeptides during time of exposure with cross-linkers.

Antibody production. To further obtain specific probes for cytochrome $b$, antibodies were produced against our purified 


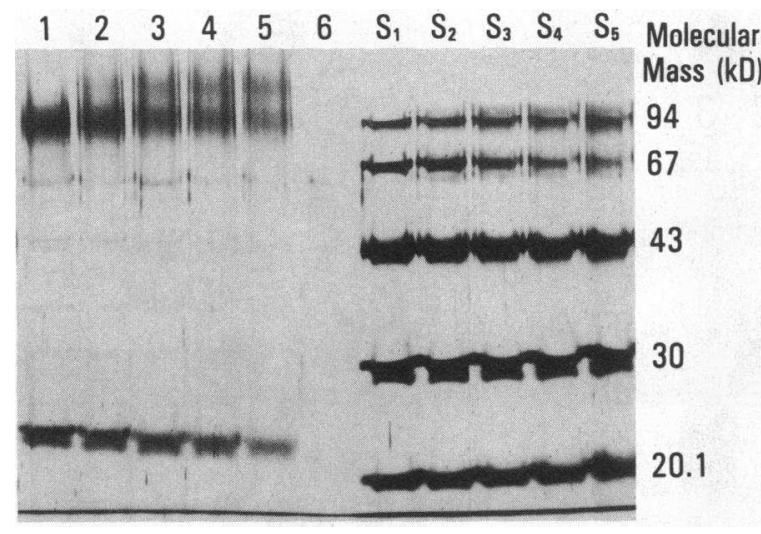

Figure 5. Cross-linking of detergent-solubilized cytochrome $b .1 \mu \mathrm{g}$ of purified cytochrome $b$ (lanes 1-5) or $1 \mu \mathrm{g}$ each of standard proteins (lanes $S_{2}-S_{5}$ ) were cross-linked with $0.25 \mathrm{mM}$ DSS for various lengths of time and then subjected to reduced SDS-PAGE on $11 \%$ (wt/vol) polyacrylamide gel as described in Methods. Standard proteins included phosphorylase B (94 kD), BSA (67 kD), ovalbumin (43 kD), carbonic anhydrase (30 kD), and soybean trypsin inhibitor $\left(20 \mathrm{kD}\right.$ ). Lanes $l$ and $S_{l}$, control cytochrome $b$, standards (no crosslinking). Lanes 2 and $S_{2}, 2$ min of cross-linking. Lanes 3 and $S_{3}, 10$ min of cross-linking. Lanes 4 and $S_{4}, 20$ min of cross-linking. Lanes 5 and $S_{5}, 40$ min of cross-linking. Lane 6 , sample buffer only, no protein.

preparation. To assay antibody titers, we developed an ELISA. Pretreatment of microtiter wells with poly-L-lysine was necessary because the detergent in our cytochrome preparation completely inhibited its binding to the surface of the wells. Using ${ }^{125}$ I-labeled cytochrome $b$, we found that $\sim 50 \%$ of the total counts in any given microtiter well could be bound provided the well had been pretreated with poly-lysine and that the total salt concentration was $<100 \mathrm{mM}$.

Of the six rabbits immunized with cytochrome $b$, only one (R3179) responded with favorable antibody titers. The immunogen used for R3179 was eluate from immobilized heparin, which had a high cytochrome $b$ specific activity of 11.8 $\mathrm{nmol}$ heme/mg protein. This rabbit's antibody titers became maximal at $6 \mathrm{wk}$ with a titer that diluted to $1: 32,000$. The antibody titers of R3179 progressively declined after the 6- and 8-wk peaks. Boosting the animal with purified cytochrome $b$ did not increase the antibody titers.

Immunoprecipitation studies. We examined the ability of IgG from R3179 to immunoprecipitate cytochrome $b$ spectrum from detergent extracts. It was necessary to use purified immunogobulin because contaminating hemoglobin in serum samples interfered with the measurement of the cytochrome $b$ spectrum. To determine if antibody was reacting with cytochrome $b$, we compared the sucrose density gradient sedimentation profiles of cytochrome-treated with either immune or control IgG. The results of the sedimentation studies are shown in Fig. 7. Increasing the amount of immune IgG incubated with eluate from immobilized heparin resulted in a corresponding increase in the amount of cytochrome spectrum sedimented to the bottom of the sucrose gradient. There was no effect of preimmune IgG on the sedimentation profile of cytochrome $b$.

Western blotting experiments. Determination of the antigen with which the antibody reacts was carried out by Western
A
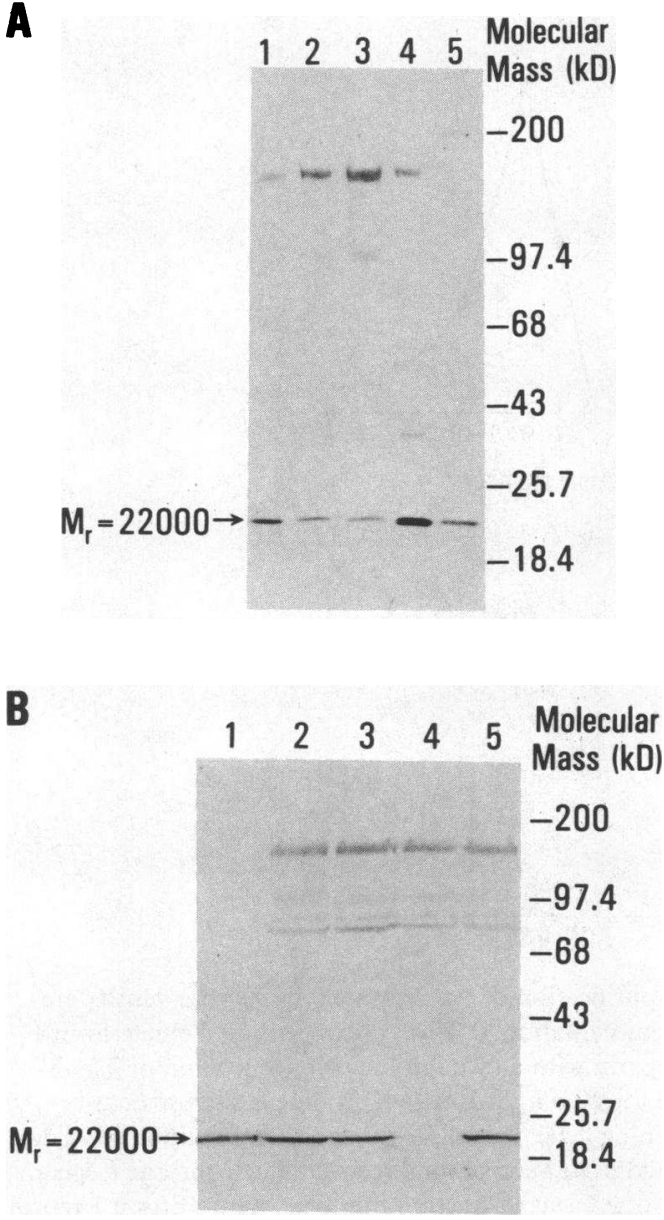

Figure 6. Western blots of R3179 IgG to cytochrome $b$ preparations and CGD neutrophils. Protein samples were subject to SDS-PAGE and then transferred to nitrocellulose as described in Methods. The nitrocellulose strips were incubated with $1 \mu \mathrm{g} / \mathrm{ml} \mathrm{R3179} \mathrm{IgG} \mathrm{fol-}$ lowed by $1 \mu \mathrm{g} / \mathrm{ml}$ of peroxidase-conjugated goat anti-rabbit IgG and then color developed as described in Methods. $(A)$ Western blot from a 7-20\% (wt/vol) polyacrylamide gradient gel. Lane $1,30 \mu \mathrm{g} \mathrm{mem-}$ brane protein from degranulated neutrophils; lane 2, $6 \mu \mathrm{g}$ protein from the $2 \%$ octylglucoside $100,000-g$ supernatant; lane $3,6 \mu \mathrm{g}$ protein from eluate from immobilized wheat germ agglutinin; lane 4, 3 $\mu \mathrm{g}$ protein from eluate from heparin ultrogel; lane $5,0.5 \mu \mathrm{g}$ of purified cytochrome $b$. (B) Purified, DFP-treated granulocytes were solubilized at $0^{\circ} \mathrm{C}$ in buffer containing $3 \mathrm{mM} \mathrm{MgCl}_{2}, 2 \mathrm{mM}$ PMSF, 20 $\mu \mathrm{g} / \mathrm{ml}$ chymostatin, $1 \%$ Triton $\mathrm{X}-100$, and $15 \mathrm{mM}$ Hepes, $\mathrm{pH} 7.4$, and centrifuged at $12,000 \mathrm{~g}$ (temperature, $4^{\circ} \mathrm{C}$ ) for $2 \mathrm{~min}$ to remove insoluble debris. The supernatants were mixed with an equal volume of sample buffer, subjected to SDS-PAGE on a 6-16\% (wt/vol) polyacrylamide gradient gel and Western blotted as described in Methods. Lane 1, $0.5 \mu \mathrm{g}$ purified cytochrome $b$; lanes 2, 3, 5, $50 \mu \mathrm{g}$ protein from three different preparations of normal granulocytes $\left(\sim 1 \times 10_{6}\right.$ cell equivalents). Lane 4, $50 \mu \mathrm{g}$ protein from X-linked C6D granulocytes ( $\sim 25 \times 10^{6}$ cell equivalents). The molecular mass of protein standards is included to the right of $(A)$ and $(B)$.

blotting techniques. Preliminary experiments using ${ }^{125} \mathrm{I}-\mathrm{la}-$ beled cytochrome $b$ revealed that the $M_{\mathrm{r}^{-}}-91,000$ subunit was difficult to electrophoretically transfer from SDS polyacrylamide gels onto nitrocellulose. We found that at a transfer current and voltage of $0.4 \mathrm{~A}$ and $115 \mathrm{~V}, \sim 35 \%$ of $\mathrm{M}_{\mathrm{r}}-91,000$ component was bound to nitrocellulose after $4 \mathrm{~h}$, which in- 


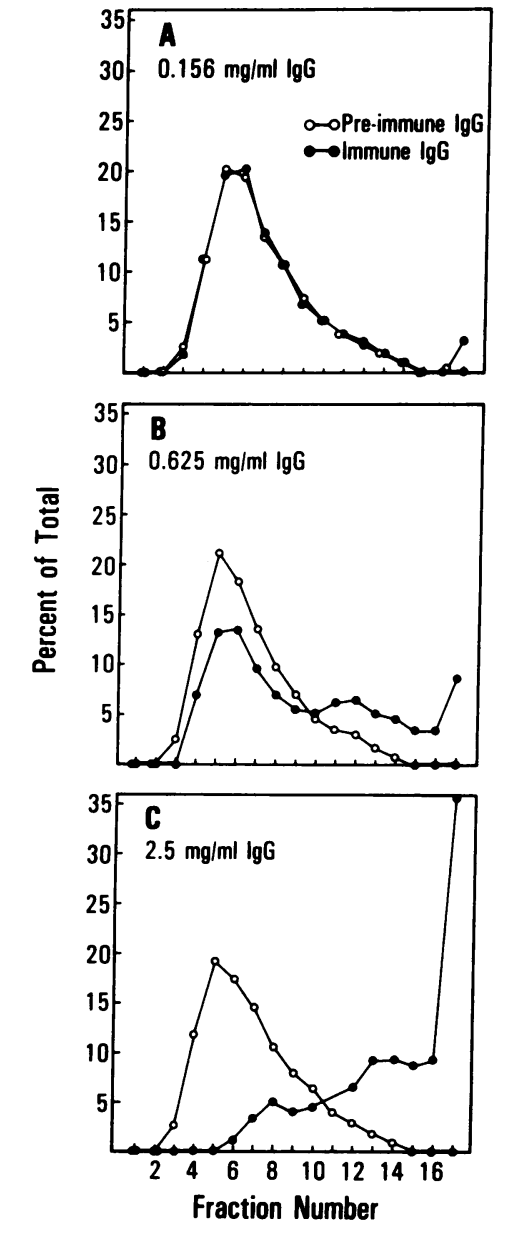

Figure 7. Immunoprecipitation of cytochrome $b$. Represented are the sucrose density gradient profiles of cytochrome $b$ after incubation with either R3179 IgG or control preimmune IgG. Concentrated eluate from immobilized heparin with cytochrome $b$ concentration of $\sim 1.5 \mu \mathrm{M}$ was incubated with either immune or preimmune IgG at the concentrations shown for $60 \mathrm{~min}$ and sedimented in linear 5-20\% sucrose density gradients containing Triton X-100 as described in Methods. Percent of total recovered cytochrome $b$ spectrum is plotted against fraction number, where fraction 1 is the top of the gradient. (Open circles) Treatment with preimmune IgG. (Closed circles) Treatment with immune IgG. Spectral recoveries were $90-100 \%$ of applied material except for the highest immune IgG treatment profile in $(C)$, which was $71 \%$.

creased to $45 \%$ after $18 \mathrm{~h}$. The $\mathrm{M}_{\mathrm{r}}-22,000$ subunit, on the other hand, was $80 \%$ transferred after $4 \mathrm{~h}$. Fig. $6 \mathrm{~A}$ shows the Western blotting profiles of $\mathrm{R} 3179 \mathrm{IgG}$ to protein samples taken from various stages of purification of cytochrome $b$ and separated on a $7-20 \%(\mathrm{wt} / \mathrm{vol})$ polyacrylamide gradient gel. Note the complete absence of labeling of the $M_{r}-91,000$ polypeptide, especially in lanes 4 and 5 , where there is at least 0.5 and $0.2 \mu \mathrm{g}$ of this species bound to the nitrocellulose, respectively. The most likely explanation for the blotting profiles shown in Fig. 6 $A$ is that $\mathrm{R} 3179 \mathrm{IgG}$ is reacting primarily with the $\mathrm{M}_{\mathrm{r}}-22,000$ component of cytochrome $b$. However, we cannot exclude the possibility of the loss of antigenicity of the larger subunit upon SDS denaturation and electrophoretic manipulation.

The presence of other labeled protein bands in Fig. $6 \mathrm{~A}$ suggests that the antibody reacts with other neutrophil proteins. As shown in lane 4, the antibody has labeled polypeptides with $M_{r}$ values of $22,000,35,000$, and 170,000 . Because this lane contains the immunogen to which the rabbit was immunized, these polypeptides are probably recognized specifically. The other labeled band of $M_{r} 100,000-110,000$ present in the more crude protein sample, lanes 2 and 3 , is probably the result of nonspecific labeling or cross-reactivity of the antibody. Western blots of preimmune IgG to the same fractions resulted in a complete absence of labeled protein bands (data not shown).

Fig. $6 \mathrm{~B}$ depicts a comparison of the Western blotting profiles of R3179 IgG to granulocytes from normal individuals and a patient (J.C.) with X-linked CGD. The neutrophils from

this CGD patient have a spectrophotometric absence of cytochrome $b$ and have no NADPH oxidase activity $(41,42)$.

Comparison of the blotting profile of X-linked CGD granulocytes (Fig. $6 \mathrm{~B}$, lane 4 ) to the profiles of normal granulocytes (lanes $2,3,5$ ) reveals a complete absence of the $M_{r}-22,000$ polypeptide in the CGD neutrophils. Since the blotting profiles of the higher molecular weight bands are the same in the control vs. CGD neutrophil lanes, the absence of labeling of the $M_{r}-22,000$ polypeptide in lane 4 is not likely to be a staining artefact. We have also confirmed the absence of the $\mathrm{M}_{\mathrm{r}}-22,000$ polypeptide in five other patients with X-linked CGD. Also shown in Fig. $6 B$ is the blotting profile of purified cytochrome $b$ (lane 1 ), which again demonstrates a lack of reactivity of the antibody with the $M_{r}-91,000$ component of the cytochrome.

\section{Discussion}

The purpose of this study was to purify cytochrome $b$ with a sufficiently high yield from human peripheral blood neutrophils so as to be practical for biochemical and immunological analysis. Specific emphasis was placed on the investigation of the possible glycoprotein nature of cytochrome $b$ and to resolve current discrepancies reported in the literature for the size of the cytochrome.

The two protein species of $M_{r} 91,000$ and 22,000 identified in this report may possibly explain these latter discrepancies. The values reported by Harper et al. $(19,23)$ and Lutter et al. (20) of 70-90 kD and $127 \mathrm{kD}$ seem to be in approximate agreement with our $M_{r}-91,000$ protein species. Because the large polypeptide is heavily glycosylated, a slight technical difference in electrophoretic systems might be enough to explain the differences. The lower molecular weight values of 11-14 $\mathrm{kD}$ and $32 \mathrm{kD}$ reported by Pember et al. (17) and Bellavite et al. (18) are in approximate agreement with our lower molecular weight species with differences probably due to either proteolysis and/or interspecies variation, because bovine and porcine granulocytes were used in these latter studies.

We believe that the reason for the lack of reports of both proteins in purified cytochrome $b$ preparations lies in the variability in which these two proteins stain on SDS polyacrylamide gels. We found that using Coomassie Blue as a primary method of protein visualization was unsatisfactory because of the sizeable amounts of protein required (>20 $\mu \mathrm{g}$ ) for adequate staining intensity. To get satisfactory protein visualization, we found it necessary to silver stain under basic conditions after Coomassie staining. Fig. 8 demonstrates that silver staining under basic conditions (28) is superior to acidic silver stains (29) in visualizing both protein bands. Integration of the densitometric scans shown in Fig. 5 demonstrates two points. First, acidic silver staining is only $30-40 \%$ as effective as basic silver staining in visualizing cytochrome $b$. Second, at low staining intensities, the relative staining densities of the $M_{r}-22,000$ and $M_{r}-91,000$ species exhibit significant variability.

From the lectin binding data in this report and those from Harper et al. (19), it has become apparent that cytochrome $b$ is a glycoprotein. Our results suggest that, of the $M_{r} 91,000$ and 22,000 protein we describe, only the large subunit is significantly glycosylated. The deglycosylation experiments in this report indicate that the $M_{r}-91,000$ component of cytochrome 
A

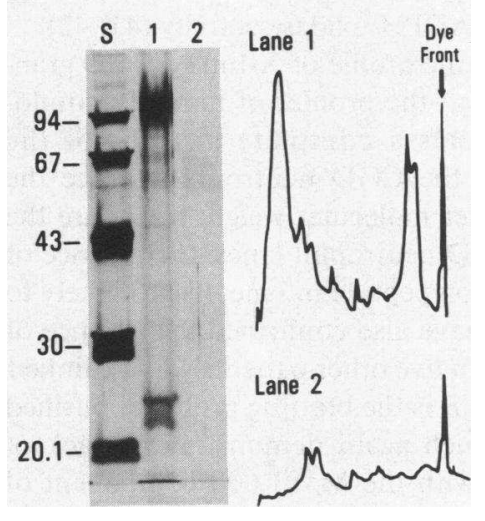

B

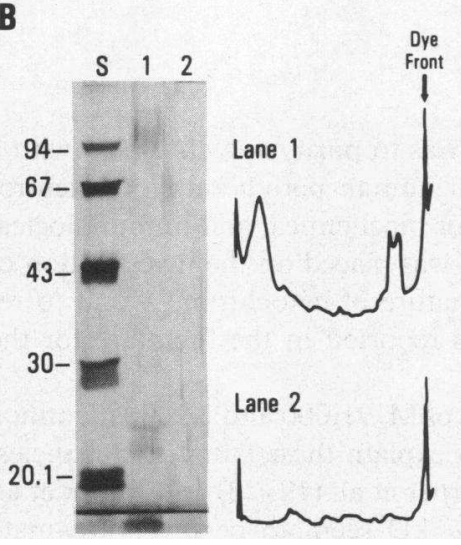

C

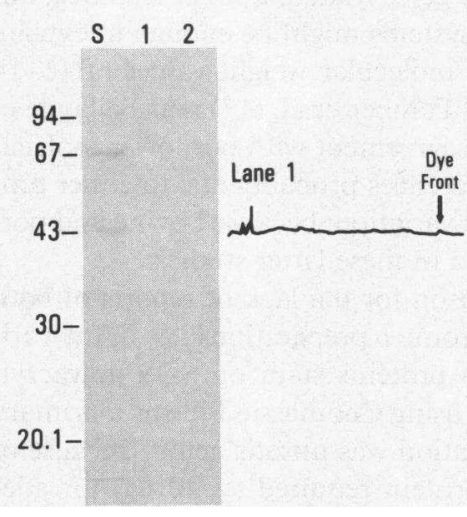

Figure 8 . Visualization of cytochrome $b$ on SDS polyacrylamide gels by various protein-staining procedures. Purified cytochrome $b(0.75 \mu \mathrm{g})$ shown in lane 1 of each panel was subjected to SDS-PAGE on $11 \%$ (wt) vol) polyacrylamide gels and stained with silver under basic conditions $(A)$, silver under acidic conditions $(B)$, or Coomassie Blue G-250 $(C)$ as described in Methods. Lane 2 of each panel represents SDS-PAGE of control buffer containing no cytochrome $b$ or protein, and lanes marked $S$ represent standard proteins $(1 \mu \mathrm{g}$ each) with their molecular mass listed to the left. Standards included phosphorylase B (94 kD), BSA (67 $k D$ ), ovalbumin (43 kD), carbonic anhydrase (30 $\mathrm{kD}$ ), and soybean trypsin inhibitor $(20.1 \mathrm{kD})$. The densitometric scans of lanes 1 and 2 of each panel are shown to the right of the respective gel lanes.

$b$ contains large amounts of $N$-linked carbohydrate and little or no $O$-linked sugars. This result suggests that the polypeptide core of the large subunit has a molecular mass of $\sim 50,000 \mathrm{D}$. Although we cannot conclude that the smaller $M_{r}-22,000$ component of cytochrome $b$ is not glycosylated, our inability to detect either $N$ - or $O$-linked carbohydrate suggests it is not glycosylated to any substantial extent. Additionally, Western blotting experiments with peroxidase-conjugated wheat germ agglutinin have failed to label the $\mathrm{M}_{\mathbf{r}}-22,000$ protein under conditions that label the $M_{r}-91,000$ component (Parkos, C. A., A. J. Jesaitis, and R. A. Allen, unpublished observations).

Because it is unlikely that the $M_{r}-91,000$ and $M_{r}-22,000$ proteins described in this report would copurify randomly, we hypothesize that these two proteins are closely associated at

least in detergent extracts. Evidence supporting the association of these two proteins is significant. First, we are unable to detect carbohydrate on the smaller subunit even though lectin affinity chromatography was employed as a purification step. Second, the two proteins copurify identically on gel filtration columns (Parkos, C. A., A. J. Jesaitis, and R. A. Allen, unpublished observations) and sucrose density gradients even though their size disparity should have permitted their resolution. Third, the two proteins can be cross-linked under conditions that do not cross-link standard control proteins. Furthermore, cross-linking does not influence the sedimentation behavior of the cytochrome in sucrose density gradients. Lastly, antibody that immunoprecipitates spectral activity from detergent extracts binds to the $M_{r}-22,000$ species and not the $M_{r}-91,000$ species on Western blots.

The nature of the apparent association between the $M_{r}-91,000$ and $M_{r}-22,000$ proteins is not clear. It is not due to disulfide linkage because no sensitivity to reduction is observed when comparing SDS-PAGE analysis under nonreducing and reducing conditions. In addition it is not dependent on the activation state of the cells on which the purification was performed. Although we cannot absolutely rule out proteolysis as the origin of the smaller protein, every precaution was taken to minimize proteolysis. Cells were treated with DFP before degranulation and cavitation. Degranulation before lysis reduced the content of granule hydrolytic enzymes in the cavitate. Nitrogen cavitation was performed under conditions that minimize the breakage of any remaining granules, and all subsequent purification steps contained phenylmethylsulfonic acid and chymostatin, which have been shown to inhibit proteolysis in whole neutrophil detergent extracts by greater than $85 \%$ (43). The measures taken to avoid proteolysis appear to have been successful because the SDS polyacrylamide gel banding patterns at the various stages of purification are stable for months at $4^{\circ} \mathrm{C}$ with no apparent changes.

Our finding of the absence of the $M_{r}-22,000$ species in granulocytes from patients with $\mathrm{X}$-linked CGD provides strong evidence that this protein is a functional component of cytochrome $b$. Therefore, if we assume that the copurification is not the result of some nonspecific association occurring after cell lysis or membrane solubilization, then our results would suggest that the human neutrophil cytochrome $b$ is a heterodimer of a heavily glycosylated polypeptide $\left(M_{r} 91,000\right)$ with a polypeptide core of $\sim 50 \mathrm{kD}$ and an unglycosylated $22-\mathrm{kD}$ polypeptide. In addition to the evidence in this report, this hypothesis is supported by our hydrodynamic analysis of the size of the detergent-solubilized cytochrome showing that the molecular mass of the cytochrome is $\sim 100-135 \mathrm{kD}(21)$. The rough correspondence of staining density of the two polypeptides separated on silver-stained SDS-PAGE shown in Fig. $8 A$ is also not inconsistent with this view.

It is not known which of the two polypeptides described in this report contains the heme prosthetic group. In our hands, separation of the two species has only resulted in denaturation of the heme spectrum. Comparison of the properties of our protein preparation with those of other nonmitochondrial membrane-bound $b$-cytochromes such as cytochrome $b_{561}(44$, 45) and cytochrome $b_{5}(46)$ would suggest that the $\mathrm{M}_{\mathrm{r}}-22,000$ species is more likely to contain heme due to its size and apparent lack of carbohydrate. The absence of the $M_{r}-22,000$ species in CGD granulocytes with a spectrophotometric absence of cytochrome $b$ supports this contention. 
If the smaller polypeptide we describe contains the heme prosthetic group then our findings are compatible with the recent results of Royer-Pokora et al. (47) who have reported the sequence of the transcript for the gene responsible for $\mathrm{X}$ linked, cytochrome $b$-negative CGD. The transcript they report does not show any significant homology to previously sequenced cytochromes and suggests the absence of a hemebinding region. In addition, the amino acid composition is different than that reported by Harper et al. (23) and Lutter et al. (20) for purified cytochrome $b$. However, because the amino analyses reported by these authors was not performed on the individual polypeptides resolved by SDS-PAGE they cannot be expected to match those reported by Royer-Pokora. This problem is further compounded by other glycoprotein contaminants in the preparation acknowledged by Harper et al. yet still used for the amino acid analyses.

The size and sequence of the transcript reported by RoyerPokora et al. is, however, consistent with our view of the size and physicochemical characteristics of the $M_{r}-91,000$ species. This putative subunit is heavily glycosylated and may not carry the heme group. Furthermore, because the $M_{r}-22,000$ polypeptide is absent in patients with $\mathrm{X}$-linked CGD, it is possible that the presence of functional $M_{r}-91,000$ subunit is required for the cellular processing of the $\mathrm{M}_{\mathrm{r}}-22,000$ component.

\section{Note Added in Proof}

During the review of this manuscript, we engaged in a collaboration with M. Dinauer and S. Orkin and confirmed that the large subunit of purified cytochrome $b$ was indeed the product of the X-linked gene whose deletion is responsible for CGD (48). This confirmation was based on the finding that antibodies made against cDNA-derived synthetic peptides and fusion proteins cross-reacted with the $M_{\mathrm{r}}-91,000$ polypeptide in its intact and deglycosylated form. Subsequently, Segal (49) published a revision of his earlier purification procedure which included an undocumented velocity sedimentation step and a second revision for the molecular weight of cytochrome $b$. Also reported was the existence of a copurifying $23-\mathrm{kD}$ protein and the absence of both proteins in granulocytes from X-linked CGD patients. The latter conclusion was based on the assumptions that $(a)$ the cytochrome purifies identically from CGD as from normal cells, and $(b)$ the antibody used to detect the $23-\mathrm{kD}$ protein was specific for the cytochrome in spite of its inability to immunoprecipitate the inferred " $\alpha-\beta$ " heterodimeric complex. In addition, because the amino acid composition for the large protein determined by him and co-workers did not match that predicted by sequence of the X-CGD gene, Segal also concluded that the cytochrome was not coded for by this gene. Most recently however, Segal and co-workers reversed their conclusion and published the amino acid sequence for the $90-\mathrm{kD}$ polypeptide which matched that predicted by Royer-Pokora et al. (47) with an additional piece at the $\mathrm{NH}_{2}$-terminal end (50). This latter observation now fully confirms our purification and results. In addition, our physicochemical studies on the hydrodynamic and cross-linking properties of this cytochrome (21, 51) present a much stronger case for its heterodimeric nature than a simple copurification.

\section{Acknowledgments}

Special thanks to Dr. J. Curnutte for important discussion and for generously supplying CGD neutrophils. We wish to thank Velda Comstock and Dian Caudebec for excellent secretarial and editorial work.
This work was supported by United States Public Health Service grants AI-17354, ROI AI-22735, and RR-00833. Charles A. Parkos is the recipient of National Institute of General Medicine Sciences National Research Award PHFGM07198 from the University of California School of Medicine, San Diego, CA. A. J. Jesaitis is the recipient of an American Heart Association (AHA) Established Investigator Award, with funds contributed in part by the California Affiliate of the AHA.

\section{References}

1. McRipley, R. J., and A. J. Sbarra. 1967. The role of the phagocyte in host-parasite interactions. J. Bacteriol. 94:1417-1424.

2. Mandell, G. L. 1974. Bactericidal activity of aerobic and anaerobic polymorphonuclear neutrophils. Infect. Immun. 9:337-341.

3. Lehrer, R. I., and M. J. Cline. 1969. Interaction of Candida albicans with human leukocytes and serum. J. Bacteriol. 98:996-1004.

4. Babior, B. M., R. S. Kipnes, and J. T. Curnutte. 1973. Biological defense mechanisms: production by leukocytes of superoxide. A potential bactericidal agent. J. Clin. Invest. 52:741-744.

5. Briggs, R. T., D. B. Drath, M. L. Karnovsky, and M. J. Karnovsky. 1975. Localization of NADH oxidase on the surface of human polymorphonuclear leukocytes by a new cytochemical method. J. Cell Biol. 67:566-568.

6. Iyer, G. Y. N., M. F. Islam, and J. H. Quastel. 1961. Biochemical aspects of phagocytosis. Nature (Lond.). 192:535-541.

7. Badwey, J. A., and M. L. Karnovsky. 1980. Active oxygen species and the functions of phagocytic leukocytes. Annu. Rev. Biochem. 49:695-726.

8. Karnovsky, M. L., and J. A. Badwey. 1983. Determinants of the production of active oxygen species by granulocytes and macrophages. J. Clin. Chem. Clin. Biochem. 21:545-553.

9. Segal, A. W., and O. T. G. Jones. 1978. Novel cytochrome $b$ system in phagocytic vacuoles of human granulocytes. Nature (Lond.). 276:515-517.

10. Segal, A. W., and O. T. G. Jones. 1979. Reduction and subsequent oxidation of a cytochrome $b$ of human neutrophils after stimulation with phorbol myristate acetate. Biochem. Biophys. Res. Comm. 88:130-134.

11. Segal, A. W., O. T. G. Jones, D. Webster, and A. C. Allison. 1978. Absence of a newly described cytochrome $b$ from neutrophils of patients with chronic granulomatous disease. Lancet. ii:446-449.

12. Hamers, M. N., M. deBoer, L. J. Meerhof, R. S. Weening, and D. Roos. 1984. Complementation in monocyte hybrids revealing genetic heterogeneity in chronic granulomatous disease. Nature (Lond.). 307:553-555.

13. Gabig, T. G., E. W. Schervish, and J. T. Santinga. 1982. Functional relationship of the cytochrome $b$ to the superoxide-generating oxidase of human neutrophils. J. Biol. Chem. 257:4114-4119.

14. Bellavite, P., A. R. Cross, M. C. Serra, O. T. G. Jones, and F. Rossi. 1983. The cytochrome $b$ and flavin content and properties of the $\mathrm{O}_{2}^{-}$forming NADPH oxidase solubilized from activated neutrophils. Biochim. Biophys. Acta. 746:40-47.

15. Cross, A. R., F. K. Higson, and O. T. G. Jones. 1982. The enzymic reduction and kinetics of oxidation of cytochrome $b_{245}$ of neutrophils. Biochem. J. 204:479-485.

16. Cross, A. R., O. T. G. Jones, A. M. Harper, and A. W. Segal. 1981. Oxidation-reduction properties of the cytochrome $b$ found in the plasma membrane fraction of human neutrophils. Biochem. J. 194:599-606.

17. Pember, S. O., B. L. Heyl, J. M. Kinkade, Jr., and J. D. Lambeth. 1984. Cytochrome $b_{558}$ from (bovine) granulocytes. J. Biol. Chem. 259:10590-10595.

18. Bellavite, P., E. Papini, L. Zeni, V. Della Bianca, and F. Rossi. 1985. Studies on the nature and activation of $\mathrm{O}_{2}^{-}$-forming NADPH oxidase of leukocytes. Identification of a phosphorylated component of the active enzyme. Free Radical Research Communications. 1:11-29. 
19. Harper, A. M., M. J. Dunne, and A. W. Segal. 1984. Purification of cytochrome $b-245$ from human neutrophils. Biochem. $J$. 219:519-527.

20. Lutter, R., M. L. J. van Schaik, R. V. van Zwieten, R. Wever, D. Roos, and M. N. Hamers. 1985. Purification and partial characterization of the $b$-type cytochrome from human polymorphonuclear leukocytes. J. Biol. Chem. 260:2237-2244.

21. Parkos, C. A., R. A. Allen, C. G. Cochrane, and A. J. Jesaitis. 1986. Characterization of purified cytochrome $b_{559}$ from the plasma membrane of stimulated human granulocytes. J. Cell Biol. 103:510a.

22. Henson, P. M., and Z. G. Oades. 1975. Stimulation of human neutrophils by soluble and insoluble aggregates. J. Clin. Invest. 56:1053-1061.

23. Harper, A. M., M. F. Chaplin, and A. W. Segal. 1985. Cytochrome $b-245$ from human neutrophils is a glycoprotein. Biochem. J. 227:783-788.

24. Amrein, P. C., and T. P. Stossel. 1980. Prevention of degradation of human polymorphonuclear leukocyte proteins by diisopropyl fluorophosphate. Blood. 56:442-447.

25. Borregaard, N., and A. I. Tauber. 1984. Subcellular localization of the human neutrophil NADPH oxidase. J. Biol. Chem. 259:47-52.

26. Clarke, S. 1975. The size and detergent binding of membrane proteins. J. Biol. Chem. 250:5459-5469.

27. Laemmli, U. K. 1970. Cleavage of structural proteins during the assembly of the head of bacteriophage $\mathrm{T}_{4}$. Nature (Lond.). 227:680-685.

28. Wray, W., T. Boulikas, V. Wray, and R. J. Hancock. 1981. Silver staining of proteins in polyacrylamide gels. Anal. Biochem. 118:197-203.

29. Merril, C. R., D. Goldman, S. A. Sedman, and M. H. Ebert. 1981. Ultrasensitive stain for proteins in polyacrylamide gels shows regional variation in cerebral spinal fluid proteins. Science (Wash. DC). 211:1437-1438.

30. Spiro, R. G. 1972. The carbohydrates of glycoproteins. Methods Enzymol. 28:31-43.

31. Edge, A. S., C. R. Faltynek, L. Hof, L. E. Reichert, Jr., and P. Weber. 1981. Deglycosylation of glycoproteins by trifluoromethanesulfonic acid. Anal. Biochem. 118:131-137.

32. Spiro, R. G., and V. D. Bhoyroo. 1974. Structure of the $O$-glycosidically linked carbohydrate units of fetuin. J. Biol. Chem. 249:5704-5717.

33. Bradford, M. 1976. A rapid and sensitive method for the quantitation of microgram quantities of protein utilizing the principle of protein-dye binding. Anal. Biochem. 72:248-254.

34. Undenfreind, S., S. Stein, P. Bohlen, W. Dairman, W. Leimgraber, and M. Weigle. 1972. Fluorescamine: a reagent for assay of amino acids, polypeptides, proteins and primary amines in the picomole range. Science (Wash. DC). 178:871-872.

35. Towbin, H., T. Staehelin, and J. Gordon. 1979. Electrophoretic transfer of proteins from polyacrylamide gels to nitrocellulose sheets: proceedure and some applications. Proc. Natl. Acad. Sci. USA. 76:4350-4354.

36. Segal, A. W., and O. T. G. Jones. 1979. The subcellular distribution and some properties of the cytochrome $b$ component of the microbicidal oxidase system of human neutrophils. Biochem. J. 182:181-188.

37. Borregaard, N., J. M. Heiple, E. R. Simons, and R. A. Clark. 1983. Subcellular localization of the $b$-cytochrome component of the human neutrophl microbicidal oxidase: translocation during activation. J. Cell Biol. 97:52-61.

38. Parkos, C. A., C. G. Cochrane, M. Schmitt, and A. J. Jesaitis. 1985. Regulation of the oxidative response of human granulocytes to chemoattractants: no evidence for stimulated traffic of redox enzymes between endo and plasma membranes. J. Biol. Chem. 260:6541-6547.

39. Frank, R. N., and D. Rodbard. 1975. Precision of sodium dodecyl sulfate-polyacrylamide gel electrophoresis for the molecular weight estimation of a membrane glycoprotein: studies on bovine rhodopsin. Arch. Biochem. Biophys. 171:1-13.

40. Segrest, J. P., and R. L. Jackson. 1972. SDS gel electrophoresis of glycoproteins. Methods Enzymol. 28:54-63.

41. Gabig, T. G., and B. A. Lefker. 1984. Deficient flavoprotien component of the NADPH-dependent $\mathrm{O}_{2}^{-}$generating oxidase in the neutrophils from three male patients with chronic granulomatous disease. J. Clin. Invest. 73:701-705.

42. Curnutte, J. T., R. Kuver, and P. J. Scott. 1987. Activation of neutrophil NADPH oxidase in a cell-free system: partial purification of components and characterization of the activation process. J. Biol. Chem. In press.

43. Sheterline, P., and C. R. Hopkins. 1981. Transmembrane linkage between surface glycoproteins and components of the cytoplasm in neutrophil leukocytes. J. Cell Biol. 90:743-754.

44. Apps, D. K., J. G. Pryde, and J. H. Phillips. 1980. Cytochrome $b_{561}$ is identical with chromomembrin $\mathrm{B}$, a major polypeptide of chromaffin granule membranes. Neuroscience. 5:2279-2287.

45. Doung, L. T., and P. J. Fleming. 1982. Isolation and properties of cytochrome $b_{561}$ from bovine adrenal chromaffin granules. J. Biol. Chem. 257:8561-8564.

46. Spatz, L., and P. Strittmaher. 1971. A form of cytochrome $b_{5}$ that contains an additional hydrophobic sequence of $\mathbf{4 0}$ amino acid residues. P.N.A.S. 68:1042-1046.

47. Royer-Pokora, B., L. M. Kunkel, A. P. Monaco, S. C. Goff, P. E. Newburger, R. L. Baehner, F. S. Cole, J. T. Curnutte, and S. H. Orkin. 1986. Cloning the gene for an inherited human disorderchronic granulomatous disease-on the basis of its chromosomal location. Nature (Lond.). 322:32-38.

48. Dinauer, M. C., S. H. Orkin, R. Brown, A. J. Jesaitis, and C. A. Parkos. 1987. The glycoprotein encoded by the X-linked chronic granulomatous disease locus is a component of the neutrophil cytochrome $b$ complex. Nature (Lond.). 327:717-720.

49. Segal, A. W. 1987. Absence of both cytochrome $b_{245}$ subunits from neutrophils in $\mathrm{X}$-linked chronic granulomatous disease. Nature (Lond.). 326:88-91.

50. Teahan, C., P. Rowe, P. Parker, N. Totty, and A. W. Segal. 1987. The $X$-linked chronic granulomatous disease gene codes for the $\beta$ chain of cytochrome $b_{245}$. Nature (Lond.). 327:720-721.

51. Parkos, C. A., R. A. Allen, C. G. Cochrane, and A. J. Jesaitis. 1987. The $b$-cytochrome from human granulocytes purifies as an $M_{\mathrm{r}}=91,000 / M_{\mathrm{r}}=22,000$ heterodimer. J. Clin. Invest. 35:652A. 